DOI: 10.36695/2219-5521.2.2019.01

УДК 347.85

Ю.С. ШЕМШУЧЕНКО, В.В. СЕМЕНЯКА

Юрій Сергійович Шемшученко, академік НАН України і Міжнародної академії астронавтики, директор Інституту держави і права ім. В.М. Корецького НАН України*

ORCID: 0000-0002-8157-9725

Василь Васильович Семеняка, кандидат юридичних наук, старший науковий співробітник Інституту держави і права ім. В.М. Корецького НАН Україн ** $^{*}$

ORCID: 0000-0002-1621-9694

\title{
СУЧАСНИЙ СТАН ТА НЕОБХІДНІСТЬ РЕФОРМУВАННЯ КОСМІЧНОГО ЗАКОНОДАВСТВА УКРАЇНИ
}

Постановка проблеми. До категорії сучасних викликів, які стоять перед космічною галуззю України, належить актуальна проблема правового забезпечення дальшого ефективного розвитку національної космічної діяльності. Слід констатувати, що чинне космічне законодавство України не відповідає об'єктивним закономірностям і тенденціям існування та розвитку космічних відносин. Сьогодні бачимо очевидний розрив між потребами космічної практики та ії нормативно-правовим закріпленням, що обумовлює необхідність реформування національного космічного законодавства, зокрема, удосконалення інструментів системи державно-правового регулювання діяльності у сфері дослідження та використання космічного простору. У цьому контексті актуального теоретичного та практичного значення набуває вивчення й аналіз проблемних питань космічного законодавства України, практики його застосування.

Аналіз останніх досліджень і публікацій. Значний науковий внесок у вирішення окремих проблем національно-правового регулювання суспільних відносин у сфері проведення наукових космічних досліджень, створення та застосування космічної техніки, використання космічного простору зробили такі фахівці у галузі космічного права, як І.П. Андрушко, О.В. Бєглий, С.О. Негода, Н.Р. Малишева. Разом із тим теоретико-прикладні питання щодо вдосконалення відповідного правового регулювання потребують більш широкого та глибокого наукового дослідження.

Формулювання мети статті. Метою даної статті є дослідження сучасного стану правового регулювання космічних відносин, виявлення недоліків та прогалин, розробка теоретико-методологічних засад та напрацювання практичних пропозицій щодо перспективних напрямів його вдосконалення.

Виклад основного матеріалу. Після розпаду Радянського Союзу, володіючи потужним науковотехнічним і виробничим космічним потенціалом, Україна як самостійний учасник міжнародних відносин розпочала свій тернистий шлях у напрямі проведення наукових космічних досліджень, створення ракетно-космічної техніки, використання космічного простору. Вона приступила до провадження космічної діяльності фактично в умовах космічно-правового вакууму - відсутності національної космічної політики та законодавства, досвіду їхнього формування і реалізації.

Найпершим актом національного космічного законодавства став Указ Президента України від 29 лютого 1992 р. № 117 «Про створення Національного космічного агентства України»¹ (зараз - ДКА

(C) Ю.С. Шемшученко, В.В. Семеняка, 2019

* Yuriy Shemshuchenko, Academician of the NAS of Ukraine and International Academy of Astronautics, director of V.M. Koretsky Institute of state and law of the NAS of Ukraine

${ }^{* *}$ Vasyl Semenyaka, Ph.D. in law, Senior Researcher of V.M. Koretsky Institute of state and law of the NAS of Ukraine 
України), яким закладено правові підвалини для становлення та розвитку космічної галузі України, формування національного космічного права. Утворення космічного агентства відбулося при Кабінеті Міністрів України. На космічне агентство покладалася, зокрема, розробка концептуальних основ державної політики в галузі дослідження й використання космічного простору; координація діяльності органів державної виконавчої влади, науково-дослідних установ, підприємств і організацій космічної галузі з питань організації та проведення космічних робіт.

Водночас невідкладного вирішення потребувало створення економіко-правових умов для збереження та розвитку космічної галузі, визначення пріоритетних напрямів космічних досліджень наукового, прикладного та оборонного характеру; перспектив міждержавного і міжнародного співробітництва, реалізації космічних проектів тощо. Реагуючи на пострадянські космічні виклики, космічним агентством разом з Конструкторським бюро «Південне» та Академією наук України розроблено стратегічний документ української космонавтики - проект космічної програми․․ Надалі Урядом України була затверджена до виконання Державна космічна програма України на 1994-1997 pp. ${ }^{3}$, якою передбачалися та реалізовані закладені заходи щодо збереження наукового та виробничого потенціалу космічної галузі на користь національної економіки і безпеки країни, а також виходу України на міжнародні ринки космічних послуг.

Сучасний правовий фундамент для формування та розвитку української космонавтики міститься у ст. 92 Основного Закону4, якою передбачено, що засади освоєння космічного простору встановлюються виключно законами України. На розвиток конститутивного положення було прийнято Закон України «Про космічну діяльність» ${ }^{5}$, котрим визначено загальні правові засади здійснення космічної діяльності в Україні та під юрисдикцією України поза ії межами. Водночас установлено, що його положення поширюються на всі види діяльності, пов'язаної з дослідженням і використанням космічного простору.

Аналізований космічний закон став стрижневим і системоутворюючим актом системи національного космічного законодавства, що спрямований на правове врегулювання багатоаспектних космічних відносин. У ньому наведено тлумачення ряду космічних термінів і понять, визначається мета і засади космічної діяльності, закріплено правові основи організації та безпеки національної космічної діяльності, загальні вимоги до створення та експлуатації космічної техніки, провадження космічної діяльність у сфері оборони та безпеки України, а також передбачено норми щодо участі України у міжнародному космічному співробітництві. Вочевидь норми Закону унормували особливості організації та здійснення національної космічної діяльності відповідно до тогочасної космічної ідеології та політики. Іншими словами, його положення відповідали вимогам часу, наявному космічному потенціалу та практиці провадження національної космічної діяльності.

Однак, як показує правозастосовна космічна практика, норми цього Закону тепер не відповідають сучасним викликам і загрозам у сфері національної космічної діяльності.

У даний час українська космічна галузь знаходиться у вкрай скрутному становищі. Нині очевидні істотні втрати українських позицій на світовому ринку космічних послуг і технологій. Припинення реалізації міжнародного космічного проекту «Алкантара Циклон Спейс» щодо будівництва та використання українсько-бразильського космодрому зі здійснення запусків українських ракет-носіїв «Циклон-4», фінансовий крах космічного проекту «Морський старт» (там використовувалася вітчизняна ракета-носій «Зеніт-3SL») є тими економіко-правовими чинниками, котрі негативно вплинули на міжнародний вектор розвитку національної космонавтики. Разом із тим припинення відносин з Російською Федерацією у сфері дослідження та використання космічного простору унеможливлює подальшу космічну співпрацю держав, зокрема, в межах спільного космічного проекту «Дніпро». Під питанням подальше використання об'єктів космічної діяльності українського походження - відповідних систем стикування російських космічних кораблів до Міжнародної космічної станції.

Крім проблем суто міжнародного характеру, додалися й внутрішні проблеми, які пов'язані з відсутністю ефективних економіко-правових умов для розвитку національної космічної діяльності. Натепер паралізована реалізація значущого для формування Національної системи супутникового зв'язку України вітчизняного космічного проекту «Либідь». Надзвичайно гострою стоїть проблема забезпечення імпортозаміщення невід'ємних складових частин української ракетно-космічної техніки, істотна частка яких - російського виробництва. Виокремлюється й проблема диверсифікації розвитку космічних підприємств.

Сьогодні необхідне усвідомлення на державному рівні значення космічної діяльності для забезпечення інноваційного розвитку високотехнологічних галузей національної економіки. Аналіз змісту урядових стратегічних документів дає змогу зробити припущення про те, що перспективи космічної галузі $є$ обнадійливими. Передбачається, зокрема, освоєння нових технологій високотехнологічного розвитку ракетно-космічної галузі, створення нових поколінь техніки і технологій в ракетно-космічній галузі, розвиток систем навігації та керування ракетною технікою, створення й експлуатація у найближчі роки угрупування українських космічних апаратів у національних інтересах ${ }^{6}$.

Втім, зазначені космічні орієнтири здебільшого $є$ нереалізованими у силу різноманітних причин. Насамперед це пов'язано з обмеженими можливостями бюджетного фінансування проектів та заходів 
загальнодержавної космічної програми. Нині держава не має економічної можливості забезпечити належну фінансову підтримку наукових космічних досліджень; розробку, виготовлення та експлуатацію ракетно-космічної техніки тощо. Останні роки космічна діяльність здійснюється за відсутності космічної програми, яка має затверджуватися Верховною Радою України на кожні п’ять років.

Найголовніше питання, що потребує вирішення, - це створення державою організаційних, економічних і правових умов для забезпечення подальшого розвитку національної космічної діяльності, визначення іï інноваційно-інвестиційної привабливості. Вочевидь без активної участі держави запровадження ефективних інструментів правового регулювання космічних відносин не можна розраховувати на сталий розвиток вітчизняної космічної галузі.

Космічна галузь має перейти до реальних інноваційно-інвестиційних засад формування, оскільки іiі розвиток в умовах дефіциту бюджетного фінансування неможливо забезпечити без вкладення інвестиційних коштів. Відтак $є$ потреба створення дієвого механізму правового регулювання відносин, насамперед комерціалізації космічної діяльності, напрацювання системи заходів та принципів державного регулювання, спрямованих на організацію й підтримку міжнародної та національної космічної діяльності, стимулювання приватного сектору економіки та залучення позабюджетних, приватних джерел фінансування космічних проектів і програм.

Сучасний стан космічного законодавства України викликає багато обгрунтованих нарікань і критики. Закон України «Про космічну діяльність» містить значну кількість норм, які не мають належного правового механізму їхньої реалізації. Наприклад, на розвиток положень ст. ст. 12, 13, 27 цього Закону Кабінетом Міністрів України досі не затверджені Правила сертифікації космічної техніки та Правила реєстрації космічних апаратів в Україні, а Президентом України - Порядок взаємодії Міністерства оборони України і центральних органів виконавчої влади, що забезпечують формування та реалізують державну політику у сфері космічної діяльності при здійсненні космічної діяльності.

Водночас слід констатувати й значне збільшення кількості Правил космічної діяльності в Україні, затвердження яких передбачено нормою ст. 8 Закону України «Про космічну діяльність». Але потребує юридичного вирішення питання їхнього застосування суб' єктами космічної діяльності в якості джерела національного космічної права.

Нині сфера космічно-правового регулювання не охоплює особливі аспекти та специфічні умови космічного господарювання, які обумовлені змінами орієнтирів зовнішньоекономічної космічної діяльності, вітчизняного законодавства та динамічними процесами розвитку діяльності, пов'язаної з дослідженням і використанням космічного простору - виникненням нових напрямів провадження космічної діяльності, існуванням інтересу потенційних учасників господарювання до здійснення цієї діяльності тощо. Дотепер відносини у національній космічній сфері засновані виключно на державній формі власності. Відтак положення Закону не забезпечують адекватне та ефективне врегулювання складних космічних відносин, що виникають у процесі реалізації космічних проектів і програм. За таких обставин космічне законодавство не повною мірою задовольняє зростаючі потреби та інтереси суб'єктів космічної діяльності.

Водночас юридично не виваженим $є$ термінологічний апарат в галузі космічного законодавства. Значна частина космічно-правової термінології не відповідає практиці провадження космічної діяльності, не має нормативно-правового визначення таких понять і термінів, як «космічні засоби», «космічна галузь України», «космічна продукція», «міжнародний космічний проект», «міжнародна космічна діяльність» та ін. Нині потребують істотного вдосконалення вживані космічні поняття і терміни шляхом техніко-юридичного наповнення їхньої змістовної частини.

Правової уніфікації потребують поняття «об’єкти космічної діяльності» (космічна техніка) та «космічний об’єкт». Визначення ж терміна «об'єкти космічної діяльності» - визнання космічною технікою відповідних матеріальних предметів штучного походження, що проектуються, не можна вважати юридично коректним.

Очевидними є недоліки сучасної нормопроектувальної техніки щодо визначення таких базових понять космічного права, як «космічна діяльність» та «суб' єкти космічної діяльності». У визначенні «космічна діяльність» не розкривається її специфічний нормативно-правовий зміст як господарювання, а робиться тільки вказівка на види космічної діяльності: наукові космічні дослідження; використання космічного простору; розроблення, виробництво, ремонт та технічне обслуговування, випробування, експлуатація, управління об'єктами космічної діяльності (у тому числі їх агрегатами та складовими частинами); забезпечення запуску, запуск та повернення космічних апаратів, їх складових частин з космічного простору на землю7. Фактично за «бортом» космічної діяльності лишається модернізація та утилізація космічної техніки, надання космічних послуг (наприклад, передача, отримання, розповсюдження та використання інформації з космічних апаратів), створення і використання космічних технологій тощо.

Водночас законодавче тлумачення терміна «суб'єкти космічної діяльності» дається з використанням організаційно-правових форм господарювання: підприємства, установи та організації. Його конструкцію слід визначити із застосуванням сучасної правової категорії «суб' єкти господарської діяльності», яка має обов'язково охоплювати, зокрема, фізичних осіб. Саме для останніх передбачається відкрит- 
тя космічного простору для дослідження та використання, але вони не визнаються суб’ єктами національної космічної діяльності.

Водночас на законодавчому рівні не розкриваються такі важливі космічні поняття і терміни, як агрегати об’ єктів космічної діяльності, безпека космічної діяльності, використання космічного простору, експлуатація космічної техніки, космічна галузь, космічна інфраструктура, космічна станція, космічна техніка цивільного призначення, космічна техніка оборонного та подвійного призначення, космічні системи, космічні засоби, космічні послуги, космічний ракетний комплекс, космічна продукція, космічне сміття, міжнародна космічна діяльність, міжнародний космічний проект, модернізація космічної техніки, національна космічна діяльність, наземна інфраструктура, наукові космічні дослідження, прикладні види космічної діяльності, ракета-носій, складові частини об'єктів космічної діяльності та багато інших.

Таким чином, проведений аналіз норм космічного законодавства України на предмет їхньої ефективності засвідчив існування істотних недоліків: спостерігається термінологічна невпорядкованість, не розроблено юридичні механізми реалізації значної частини космічно-правових норм, окремі його положення $\epsilon$ архаїчними, мають місце суперечності у регулюванні космічних відносин, що зумовлює неоднакові підходи до тлумачення правових норм та різне їх застосування.

Закон України «Про космічну діяльність» практично вичерпав ефективну юридичну дію, оскільки зміст його космічно-правових норм не враховує нинішню специфіку розвитку відносин у сфері національної космічної діяльності. Зазначені обставини обумовлюють актуальність реформування національного космічного законодавства, удосконалення його змістовної частини, форми та системи.

3 метою вирішення існуючих галузевих проблем у нових економіко-правових та космічних реаліях, зокрема руху у напрямі демонополізації видів космічної діяльності, важливого значення набуває формування космічно-правової ідеології щодо істотного оновлення механізму правового регулювання виникнення та реалізації космічних відносин. Проведення модернізації космічного законодавства у світлі новітніх викликів національній космічній галузі має стати одним із пріоритетів космічної політики України. При цьому важливим є напрацювання конкретних правових пропозицій та визначення основних напрямів удосконалення законодавства України про космічну діяльність, насамперед модернізації норм ключового акта космічного законодавства - Закону України «Про космічну діяльність».

Зокрема, аналізовані космічні поняття і терміни мають знайти нормативне закріплення в національному космічному законодавстві. Їх визначення та удосконалення повинно відповідати нормам і принципам космічного права, а також техніко-юридичному їх змісту, який вкладається фахівцями у сфері створення та експлуатації ракетно-космічної техніки, ученими-юристами. Вочевидь без застосування наукових прийомів, методів та спеціальних космічних знань неможливо обрати найбільш оптимальну модель правового регулювання космічних відносин, спрогнозувати і оцінити наслідки їхньої реалізації.

Цьому процесу має передувати виявлення і врахування потреб та інтересів різноманітних учасників космічних відносин як державної, так і приватної форм власності, дослідження їх розвитку та сучасних змін, що пов'язано не тільки 3 прискоренням науково-технічного космічного прогресу, а й 3 неймовірно негативних впливом на них воєнної складової. Відповідно правові питання щодо створення умов для подальшого розвитку національної космічної діяльності мають стати предметом широкого обговорення та дискусій на предмет вироблення космічно-правової ідеології стосовно дальшого нормативно-правового забезпечення формування законодавства про космічну діяльність в Україні.

Останнім часом питання правового забезпечення космічних відносин були предметом законодавчих ініціатив щодо демонополізації видів космічної діяльності та вдосконалення їі державного регулювання (дозвільно-ліцензійного порядку іiі провадження) ${ }^{8}$. Так, прийнято певні законодавчі рішення щодо припинення державної монополії на розробку та експлуатацію ракет-носіїв, а також їх запуски, що, безумовно, впливає на подальший розвиток національної космічної діяльності, розширення кола суб'єктів та інвестиційну привабливість космічної галузі.

Новелами космічного законодавства України є впровадження декларативного та дозвільного порядку провадження національної космічної діяльності.

Але розробка та розгляд законопроектів засвідчує хаотичний підхід до оновлення космічно-правових норм. За надзвичайно короткий проміжок часу бачимо зміни побудови правових конструкцій законопроектів: від запровадження інструменту ліцензування, дозвільного порядку до декларативного механізму провадження космічної діяльності, нового понятійного апарату. Відповідні рішення не мають глибокого та серйозного фахового обговорення серед космічної спільноти, експертно-правової оцінки розроблених космічних норм, їх відповідності основним принципам доцільності та адекватності державної регуляторної політики у сфері провадження космічної діяльності.

Очевидно, що дозвільний та декларативний спосіб здійснення космічної діяльності не сприятиме створенню привабливих економіко-правових умов для розвитку національної космічної діяльності, а призведе до надмірного регуляторного впливу держави на цю сферу господарювання. Наразі цими інструментами не вирішується питання убезпечення космічної діяльності, яка потребує формування та реалізації комплексу правових, науково-технічних, організаційних та інших заходів. Сьогодні, яка показує космічна практика, ефективні ринкові механізми та інструменти саморегулювання при здійсненні 
національної космічної діяльності (наприклад, сертифікація, перевірка на відповідність вимогам експлуатаційної придатності, технічним регламентам) забезпечують безпеку космічної продукції для необмеженого кола осіб. Тим самим гарантується безпека держави у сфері міжнародних космічних відносин $^{9}$.

Разом із тим ДКА України розроблено актуальні та системно важливі для розвитку космічної галузі законопроекти «Про державне регулювання у сфері супутникової навігації» ${ }^{10}$ та «Про державне регулювання у сфері дистанційного зондування Землі» ${ }^{11}$. Перспективи розвитку національної діяльності у сферах дистанційного зондування Землі та супутникової навігації зумовлюють впровадження у національне космічне право нових космічних понять і термінів: аерокосмічний об'єкт дистанційного зондування Землі, дистанційне зондування Землі, діяльність 3 дистанційного зондування Землі, оператор аерокосмічних об'єктів дистанційного зондування Землі, космічні системи дистанційного зондування Землі, користувач даних дистанційного зондування Землі, національний ринок космічних інформаційних технологій, супутникова навігація, супутниковий зв'язок, глобальні навігаційні супутникові системи, національний супутниковий зв'язок.

Поміж тим космічні відносини, на наш погляд, потребують не фрагментарного правового вдосконалення, а комплексного сучасного нормативно-правового оновлення та вирішення цілого кола проблем космічної галузі з урахуванням особливостей космічної діяльності, норм міжнародного та національного космічного права. Причому специфіка космічних відносин зумовлює застосування публічно-правових і приватноправових основ та інструментів у правовому регулюванні досліджуваного типу відносин.

В основу концептуальних засад реформування космічного законодавства України має бути покладено результати прикладних наукових досліджень економічних запитів внутрішнього та зовнішнього ринків космічних послуг і технологій, особливостей використання космічних технологій у виробництві конкурентоспроможної високотехнологічної цивільної продукції, можливості трансферу останніх у суміжні сфери господарювання. При цьому мають бути враховані закономірні тенденції існування та розвитку національних космічних відносин, які повинні регулюватися створюваними космічно-правовими нормами.

Основоположне значення для подальшого розвитку космічної галузі має забезпечення ефективного державного управління космічною діяльністю. Єдиним компетентним державним органом, який забезпечував формування і реалізацію космічної політики, був центральний орган з питань космічної діяльності - ДКА України. Однак у 2012 р. зазначена норма Закону України «Про космічну діяльність» зазнала істотного корегування. Нею передбачається розмежування органу державного управління: на орган управління, що забезпечує формування космічної політики і орган управління, який забезпечує реалізацію космічної політики.

Фактично ДКА України позбавлене функції формування космічної політики, залишилось тільки забезпечення іiі реалізації. У 2019 р. повноваження щодо формування космічної політики закріплено за Управлінням координації космічної діяльності у складі департаменту стратегічного розвитку сектору оборони та безпеки Міністерства розвитку економіки, торгівлі та сільського господарства України (далі - Мінекономіки) ${ }^{12}$, де утворено відділ економіки сфери космічної діяльності та відділ аналізу супроводження міжнародних проектів у сфері космічної діяльності ${ }^{13}$. Відтак відповідальними за космічну політику стали, з одного боку, Мінекономіки - формування космічної політики, і ДКА України у частині реалізація космічної політики, - 3 другого. Унаслідок перерозподілу космічних повноважень досі цілісний правовий механізм державного регулювання космічною діяльністю де-факто розпорошується між двома державними органами в умовах відсутності правового алгоритму координації їхніх спільних дій. Проте, чи сприятиме це сталому розвитку національної космічної діяльності? Не виключається, що нормативно-правові акти Мінекономіки можуть спричинити виникнення колізій або ігнорування окремих норм космічного законодавства, що може призвести до космічно-правового хаосу у космічній галузі. Аналізовані відносини щодо органу державного регулювання космічної діяльністю потребують більш глибокого аналізу і дослідження на предмет ефективності та доцільності впровадження зазначеного поділу космічної компетенції.

Особливу важливість для розвитку космічної галузі має державне прогнозування - науково обгрунтоване передбачення векторів розвитку національної космічної діяльності на десятиліття. Тобто, держава повинна визначити вітчизняні пріоритети у напрямі дослідження та використання космічного простору, тим самим вказавши, куди має рухатись космічна галузь України.

Очевидно, що провідне місце має зайняти діяльність у сфері проектування, виготовлення та експлуатації ракетно-космічної техніки. Наявний виробничий та інтелектуальний потенціал провідних космічних підприємств України (зокрема, Конструкторського бюро «Південне» та Південного машинобудівного заводу) слід використати для досягнення сталого розвитку національної космічної діяльності.

3 метою забезпечення ефективного функціонування космічних підприємств державного сектору в умовах ринкової економіки, виготовлення ними наукоємної конкурентоспроможної космічної продукції актуальним $\epsilon$ проведення економіко-правових досліджень щодо доцільності та наслідків здійснення їх організаційно-господарських перетворень: приватизації, корпоратизації чи утворення космічної корпо- 
рації. За будь-яких умов функціонування відносин, для забезпечення сталого розвитку космічної галузі, важливо зберегти виробничі та інтелектуальні ресурси, на яких тримається національна космічна галузь, що має стратегічне значення для розвитку економіки України.

3 метою сприяння поліпшенню якості космічного законодавства України, забезпечення ефективності правового регулювання космічних відносин необхідно грунтовно теоретично опрацювати концептуальні засади реформування системи законодавства України про космічну діяльність з урахуванням досягнень сучасної науки космічного права. Отож, потрібно створити повноцінну науково обгрунтовану правову базу розвитку національної космічної діяльності.

Висновки. Найбільш ефективним способом підвищення ефективності національного космічного права, на наш погляд, має стати проведення його кодифікації. Завдяки цьому відбудеться систематизація норм космічного законодавства, оновлення інструменту правового регулювання відносин у сфері космічної діяльності, системність та узгодженість відповідного законодавства.

Основним завданням кодифікації є приведення чинного національного космічного законодавства у відповідність 3 потребами сучасного етапу та перспектив розвитку відносин у сфері дослідження й використання космічного простору. Удосконалення системи законодавства України про космічну діяльність має здійснюватися на грунтовному аналізі норм національного законодавства та практики його застосування, норм міжнародного космічного права і законодавчому досвіду провідних космічних держав світу.

Процес кодифікації повинен заповнити існуючі прогалини у правовому регулюванні космічно-правових відносин; усунути суперечності, наявні у чинному космічному законодавстві, колізії та дублювання; сприяти розробці нових універсальних космічно-правових норм; виключити застарілі та неефективні норми. Результат кодифікації - об'єднання космічно-правових норм, що регулюють космічні відносини, у якісно новий юридичний документ - Космічний кодекс України із нормативно-правовим закріпленням сучасного правового режиму провадження здійснення космічної діяльності в Україні.

У цьому документі мають знайти відображення, зокрема, актуальні питання космічно-правової термінології у сфері космічної діяльності, розвитку комерційної космічної діяльності, безпеки космічної діяльності, впровадження конкурсних засад реалізації космічних проектів і програм, забезпечення рівного доступу до провадження космічної діяльності та їі результатів. Вочевидь удосконалення норм космічного права, їх зміна та перегляд має забезпечити прогресивний розвиток національного космічного права, сприятиме розвитку космічної діяльності, а також створенню умов для розвитку космічних послуг і технологій.

1 Про створення Національного космічного агентства України: Указ Президента України від 29.02.1992 р. № 117. Космічне право України: Збірник національних і міжнародних правових актів. 5-те вид., переробл. та допов. / відповід. ред.: Е.І. Кузнєцов, Н.Р. Малишева. Київ: Атіка, 2007. С. 82-83.

2 Космічна програма України: постанова Президії Академії наук України від 06.01.1993 p. № 1. URL: https://zakon.rada. gov.ua/rada/show/v0001550-93

3 Про затвердження Державної космічної програми України: постанова Кабінету Міністрів України від 07.06.1994 р. № 371. URL: https://zakon.rada.gov.ua/laws/show/371-94-\%D0\%BF

${ }^{4}$ Конституція України від 28.06.1996 р. Відомості Верховної Ради Украӥни. 1996. № 30. Ст. 141.

5 Про космічну діяльність: Закон України від 15.11.1996 р. Космічне право Украӥни: Збірник національних і міжнародних правових актів. 5-те вид., переробл. та допов. / відповід. ред.: Е.І. Кузнєцов, Н.Р. Малишева. Київ: Атіка, 2007. С. $15-28$.

6 Про затвердження Середньострокових пріоритетних напрямів інноваційної діяльності галузевого рівня на 20172021 роки: постанова Кабінету Міністрів України від 18.10.2017 р. № 980. Офічійний вісник Украӥни. 2018. № 1. Ст. 1.

7 Проект Закону про внесення змін до деяких законодавчих актів України щодо державного регулювання космічної діяльності. URL: http://w1.c1.rada.gov.ua/pls/zweb2/webproc4_1?pf3511=66298

8 Див.: Проект Закону про внесення змін до деяких законодавчих актів України щодо державного регулювання космічної діяльності. URL: http://w1.cl.rada.gov.ua/pls/zweb2/webproc4_1?pf3511=66298

${ }^{9}$ Semenyaka Vasyl. The Current State of Deregulation of Space Activities in Ukraine. Advanced Space Law, Volume 3, 2019. C. $115-116$.

10 Проект Закону України «Про державне регулювання у сфері супутникової навігації». URL: http://www.nkau.gov.ua/ua/ activity/rehuliatorna-polityka/povidomlennia-pro-opryliudnennia

11 Проект Закону України «Про державне регулювання у сфері дистанційного зондування Землі». URL: http://www.nkau. gov.ua/ua/activity/rehuliatorna-polityka/povidomlennia-pro-opryliudnennia

12 Про затвердження Положення про управління координації космічної діяльності департаменту стратегічного розвитку сектору оборони та безпеки: наказ Міністерства економічного розвитку і торгівлі України від 27.02.2019 р. № 328 . URL: https://zakon.rada.gov.ua/rada/show/v0328731-19

13 Про затвердження положень про структурні підрозділи управління координації космічної діяльності департаменту стратегічного розвитку сектору оборони та безпеки: Наказ Міністерства економічного розвитку і торгівлі України від 13.08.2019 p. № 1384. URL: https://zakon.rada.gov.ua/rada/show/v1384731-19

References:

Ukaz Prezydenta Ukrainy vid 29.02.1992 r. № 117 «Pro stvorennia Natsional'noho kosmichnoho ahentstva Ukrainy». Kosmichne pravo Ukrainy: Zbirnyk natsional'nykh i mizhnarodnykh pravovykh aktiv (vidpovid. redaktory: E.I. Kuznietsov, N.R. Malysheva) (2007). Vyd. 5-te, pererobl. ta dopov. K.: Atika, 82-83 [in Ukrainian]. 
Postanova Prezydii Akademii nauk Ukrainy vid 06.01.1993 r. № 1 «Kosmichna prohrama Ukrainy». URL: https://zakon.rada. gov.ua/rada/show/v0001550-93 [in Ukrainian].

Postanova Kabinetu Ministriv Ukrainy vid 07.06.1994 r. № 371 «Pro zatverdzhennia Derzhavnoi kosmichnoi prohramy Ukrainy». URL: https://zakon.rada.gov.ua/laws/show/371-94-\%D0\%BF [in Ukrainian].

Konstytutsiia Ukrainy vid 28.06.1996 r. (1996). Vidomosti Verkhovnoi Rady Ukrainy, 30, 141 [in Ukrainian].

Zakon Ukrainy «Pro kosmichnu diial'nist'» vid 15.11.1996 r. Kosmichne pravo Ukrainy: Zbirnyk natsional'nykh i mizhnarodnykh pravovykh aktiv (vidpovid. redaktory: E.I. Kuznietsov, N.R. Malysheva). (2007). vyd. 5-te, pererobl. ta dopov. K.: Atika, 15-28 [in Ukrainian].

Postanova Kabinetu Ministriv Ukrainy vid 18.10.2017 r. № 980 «Pro zatverdzhennia Seredn’ostrokovykh priorytetnykh napriamiv innovatsijnoi diial'nosti haluzevoho rivnia na 2017-2021 roky» (2018). Ofitsijnyj visnyk Ukrainy, 1. 1 [in Ukrainian].

Proekt Zakonu pro vnesennia zmin do deiakykh zakonodavchykh aktiv Ukrainy schodo derzhavnoho rehuliuvannia kosmichnoi diial'nosti URL: http://w1.c1.rada.gov.ua/pls/zweb2/webproc4_1?pf3511=66298

Proekt Zakonu pro vnesennia zmin do deiakykh zakonodavchykh aktiv Ukrainy schodo derzhavnoho rehuliuvannia kosmichnoi diial'nosti URL: http://w1.c1.rada.gov.ua/pls/zweb2/webproc4_1?pf3511=66298 [in Ukrainian].

Semenyaka, Vasyl. (2019). The Current State of Deregulation of Space Activities in Ukraine. Advanced Space Law, Volume 3, 115-116 [in English].

Proekt Zakonu Ukrainy «Pro derzhavne rehuliuvannia u sferi suputnykovoi navihatsii». URL: http://www.nkau.gov.ua/ua/acti vity/rehuliatorna-polityka/povidomlennia-pro-opryliudnennia [in Ukrainian].

Proekt Zakonu Ukrainy «Pro derzhavne rehuliuvannia u sferi dystantsijnoho zonduvannia Zemli». URL: http://www.nkau.gov. ua/ua/activity/rehuliatorna-polityka/povidomlennia-pro-opryliudnennia [in Ukrainian].

Nakaz Ministerstva ekonomichnoho rozvytku i torhivli Ukrainy vid 27.02.2019 r. № 328 «Pro zatverdzhennia Polozhennia pro upravlinnia koordynatsii kosmichnoi diial'nosti departamentu stratehichnoho rozvytku sektoru oborony ta bezpeky». URL: https://zakon.rada.gov.ua/rada/show/v0328731-19 [in Ukrainian].

Nakaz Ministerstva ekonomichnoho rozvytku i torhivli Ukrainy vid 13.08.2019 r. № 1384 «Pro zatverdzhennia polozhen’ pro strukturni pidrozdily upravlinnia koordynatsii kosmichnoi diial'nosti departamentu stratehichnoho rozvytku sektoru oborony ta bezpeky». URL: https://zakon.rada.gov.ua/rada/show/v1384731-19 [in Ukrainian].

\section{Резюме}

Шемшученко Ю.С., Семеняка В.В. Сучасний стан та необхідність реформування космічного законодавства України.

У статті проаналізовано сучасний стан правового регулювання космічних відносин. Показано, що норми національного космічного законодавства не відповідають сучасним викликам і загрозам у сфері космічної діяльності. Доводиться важливість проведення кодифікації у галузі національного космічного законодавства. Обгрунтовуються необхідність розробки i прийняття Космічного кодексу України для підвищення рівня правового забезпечення проведення наукових космічних досліджень, створення та експлуатації космічної техніки, використання космічного простору.

Ключові слова: космічне право, космічні відносини, космічна галузь, космічна діяльність, космічне законодавство, космічний кодекс.

\section{Резюме}

Шемшученко Ю.С., Семеняка В.В. Современное состояние и необходимость реформирования космического законодательства Украины.

В статье проанализировано современное состояние правового регулирования космических отношений. Показано, что нормы национального космического законодательства не соответствуют современным вызовам и угрозам в сфере космической деятельности. Доказывается важность проведения кодификации в области национального космического законодательства. Обосновываются необходимость разработки и принятия Космического кодекса Украины для повышения уровня правового обеспечения проведения научных космических исследований, создания и эксплуатации космической техники, использования космического пространства.

Ключевые слова: космическое право, космические отношения, космическая отрасль, космическая деятельность, космическое законодательство, космический кодекс.

\section{Summary}

Yuriy Shemshuchenko, Vasyl Semenyaka. The current state and the need for reforming the space legislation of Ukraine.

The article analyzes the current state of legal regulation of space relations. It is shown that the rules of national space legislation do not meet the current challenges and threats in the field of space activities. The importance of elaboration of specific legal proposals and definition of the main directions of improvement of the legislation of Ukraine on space activity, first of all modernization of norms of the key act of space law - the Law of Ukraine «On space activity» is pointed out.

It has been investigated that the terminology apparatus in the field of space law is not legally weighted and requires a significant improvement of the used and introduction of new space concepts and terms. It is argued that the most effective way of enhancing the effectiveness of national space law is through its codification. The main task of codification is determined - to bring the current national space legislation in line with the needs of the current stage and prospects for the development of relations in the field of space exploration and use.

The necessity of carrying out a comprehensive up-to-date normative-legal updating of Ukrainian space legislation is noted, taking into account the peculiarities of space activity, rules of international and national space law. however, it is important to use public-law and private-law frameworks and tools in the legal regulation of space relations. It is envisaged that the codification process should cover filling in the gaps in the legal regulation of space-legal relations; the elimination of gaps and contradictions in current space laws, conflicts and duplications; development of new universal space laws; exclusion of outdated and ineffective norms. 
The necessity of development and adoption of the Space Code of Ukraine to increase the level of legal support for scientific space exploration, creation and operation of space technology, use of outer space is substantiated. It is offered to fix the solution of topical issues of space legal terminology in the field of space activity, development of commercial space activity, security of space activity, introduction of competitive bases for the implementation of space projects and programs, ensuring equal access to space activity and its results.

Key words: space law, space relations, space industry, space activity, space code. 